\title{
Evaluation of biological synthesized platinum nanoparticles using Ononidis radix extract on the cell lung carcinoma A549
}

\author{
Renata Dobrucka $^{1} \cdot$ Aleksandra Romaniuk-Drapała $^{2}$ - Mariusz Kaczmarek ${ }^{3}$ \\ Published online: 25 July 2019 \\ (C) The Author(s) 2019
}

\begin{abstract}
Due to the search for new methods for synthesizing nanomaterials, this work proposes the biological synthesis of platinum nanoparticles using Ononidis radix extract. The synthesized platinum nanoparticles were characterized by UV-Vis, Scanning Electron Microscopy (SEM) with EDS profile, Fourier transform infrared spectroscopy (FTIR), Transmission Electron Microscopy (TEM) and Atomic Force Microscopy (AFM). The examination conducted by means of Transmission Electron Microscopy showed the presence of spherical and hexagonal platinum nanoparticles. Atomic Force Microscopy indicated the presence of locally agglomerated nanoparticles whose size was about $4 \mathrm{~nm}$. The study also examined the influence of platinum nanoparticles on human non-small cell lung carcinoma cells A549. It was found that the mortality of cells cultured together with platinum nanoparticles increased, and the proliferative activity of A549 cells decreased gradually over time in proportion to the increasing concentration of the test substance.
\end{abstract}

Keywords Platinum nanopartilces $\cdot$ Green synthesis · Anticancer activity

\section{Introduction}

Nanoparticles are a group of materials with morphological properties smaller than a micrometer in at least one external dimension, or with a nanoscale internal structure. As a result of those changes, nanoparticles have a large surface area, which is chemically more reactive than their fine structural analogues (Ajitha et al. 2015; Bhatnagar et al. 2018). The most popular method for synthesizing nanoparticles is the chemical reduction method, which uses chemical substances as reducing agents. Even though chemical syntheses have several advantages, the use of toxic chemicals on the surface of nanoparticles and non-polar solvents in the synthesis procedure

Renata Dobrucka

renata.dobrucka@ue.poznan.pl

1 Department of Industrial Products Quality and Ecology, Faculty of Commodity Science, Poznan University of Economics, al.

Niepodległości 10, 61-875 Poznan, Poland

2 Department of Clinical Chemistry and Molecular Diagnostics, Poznan University of Medical Sciences, 49 Przybyszewskiego St, 60-355 Poznań, Poland

3 Department of Immunology, Chair of Clinical Immunology, Poznan University of Medical Sciences, Rokietnicka 5D, 60-806 Poznan, Poland limits their applications in clinical fields (Vijayaraghavan and Ashokkumar 2017). Researchers have tried to develop clean, biocompatible, non-toxic and eco-friendly methods for synthesizing nanoparticles (Dauthal and Mukhopadhyay 2016). Such an alternative may be offered by biological synthesis, which is developing rapidly due to its growing success and ease of formation of nanoparticles.

At present, scientists are carrying out intense studies focused on synthesizing metal nanoparticles with the use of various microorganisms, such as bacteria, algae, actinomycetes, fungi, yeast and viruses (Narayanan and Sakthivel 2010; Thakkar et al. 2010). If algae or plants are used, the production of nanoparticles is usually limited to the extracellular method. The use of plant extracts in biological synthesis has certain advantages: they are easily available, safe to handle, and they possess a broad viability of metabolites. Moreover, it has been found that plant extracts act both as reducing and capping agents in the process of synthesizing nanoparticles (Nasrollahzadeh et al. 2016; Baranwal et al. $2018 \mathrm{a}, \mathrm{b})$. The reduced form of metals obtained from biological synthesis is highly reactive and used in various fields, like the biological field, electrochemistry and photochemistry (Khan et al. 2017). One of great advantages of biologically synthesized nanomaterials is that they have potential applications in different areas, such as medicine or pharmacy (Baranwal et al. 2016). Matal nanoparticles are used as 
antimicrobial agents (Baranwal et al. 2018a, b). The world literature contains numerous examples of the biological synthesis of metal nanoparticle, but biological methods for synthesizing platinum nanoparticles with the use of plant materials have not been widely exploited. The literature presents several examples of the green synthesis of platinum nanoparticles with the use of, for example, leaves of Cerbera manghas (Rajathi and Nambaru 2014), Azadirachta indica (Thirumurugan et al. 2016), quail egg yolk (Nadaroglu et al. 2017), Fumariae herba (Dobrucka 2016) or pomegranate extract (Șahin et al. 2018).

In this work, the synthesis of platinum nanoparticles was carried out with the use of Ononis spinosa L, which is a species belonging to the Fabaceae family. It grows in Europe and on the sandy areas of Asia. It has trifoliate leaves and papilionaceous flowers. The roots of Ononis spinosa $L$ are ligneous and twisted, and due to their medicinal properties, they are often used in herbal medicine. Ononidis radix contains flavonoid derivatives, sterols, terpenic substances, phenolic acids and essential oil. Due to the high content of biologically active substances, Orradix was used in this study to carry out the biological synthesis of nanoparticles.

\section{Materials and methods}

\subsection{Materials}

All the reagents used in this study were purchased from Sigma-Aldrich (Poland). Milli-Q water was used throughout the experiment. All chemicals were of analytical grade.

\subsection{Synthesis of platinum nanoparticles}

Healthy samples of O.radix was obtained from Wielkopolska region (Poland, 51 ${ }^{\circ} 52^{\prime} 56^{\prime \prime} \mathrm{N}, 17^{\circ} 00^{\prime} 44^{\prime \prime} \mathrm{E}$ ). To 3 g powdered of $O$. radix, there were added $100 \mathrm{~mL}$ of double distilled water. The solution was boiled and stirred for $1 \mathrm{~h}$ at the temperature of $85{ }^{\circ} \mathrm{C}$. Next, $0.02 \mathrm{~g} \mathrm{~K}_{2} \mathrm{PtCl}_{6}$ was added into the cooled $30 \mathrm{~mL}$ extract of $O$. radix. This solution was stirred for $5 \mathrm{~h}$ in temperature $80^{\circ} \mathrm{C}$. After $10 \mathrm{~h}$, the UV-absorption spectrum of the synthesized platinum nanoparticles was monitored.

\subsection{Characterization of platinum nanoparticles}

The analysis of optical property of biological synthesized platinum nanoparticles using $O$. radix s was made using ultraviolet and visible absorption spectroscopy (spectrophotometer Cary E 500) in the range of $250 \mathrm{~nm}-600 \mathrm{~nm}$. In order to characterize the synthesized platium nanoparticles, there was conducted Fourier transform infrared spectroscopy (FTIR) using Perkin Elmer Spectrum 1000, in attenuated total reflection mode and using spectral range of 4000-380 cm1 , with a resolution of $4 \mathrm{~cm}-1$. The structure of biological synthesized platinum nanoparticles was studied using TEM (Transmission electron microscope) JEOL JEM 1200 EXII, operating at $80 \mathrm{kV}$. In this work AFM (atomic force microscope) INTEGRA SPECTRA SOLAR of NT-MDT brand and measurement tips dedicated for NSGO1 high-resolution measurements was used. The picture of biological synthesized platinum nanoparticles was prepared by means of SEM (scanning electron microscopy) SEM SU3500, Hitachi with spectral imaging system Thermo Scientific NSS (EDS).

\subsection{Evaluation of the cell cycle}

The influence of platinum nanoparticles on human cells was evaluated in vitro using the established epithelial cell line of human non-small cell lung carcinoma A549 from American Type Culture Collection (ATCC® CCL-185 ${ }^{\mathrm{TM}}$ ). Cells were cultured in Nunc Easy Flask $75 \mathrm{~cm}^{2}$ (Thermo Fisher Scientific) in RPMI-1640 culture medium with $2 \mathrm{mM} \mathrm{L-}$ glutamine (LONZA) supplemented with $10 \%$ fetal bovine serum (FBS; Sigma-Aldrich) and with $1 \%$ of a solution of antibiotic-antimycotic mixture contained $10000 \mathrm{U} / \mathrm{mL}$ penicillin, $10 \mathrm{mg} / \mathrm{mL}$ streptomycin and $25 \mu \mathrm{l} / \mathrm{mL}$ amphotericin B (Sigma-Aldrich). The cultures were kept at $37{ }^{\circ} \mathrm{C}$ in an incubator in a humidified $5 \% \mathrm{CO}_{2}$ atmosphere. Cells prepared for the test were transferred in suspension $4 \times 10^{4}$ cells per well to 24-well flat-bottomed plastic plates (TC-PLATE 24 wells, Greiner) and incubated for $24 \mathrm{~h}$ to achieve adhesion. In the course of the test, cells were treated with platinum nanoparticles in followed concentrations: $1 \mu \mathrm{g} / \mathrm{mL}, 10 \mu \mathrm{g} / \mathrm{mL}$ and $100 \mu \mathrm{g} / \mathrm{mL}$, and then were cultured for 24,48 , and $72 \mathrm{~h}$. As a control, the cells cultured without tested platinum nanoparticles solutions were used. All tests were made in triplicates.

The platinum nanoparticles effect on A549 cells was investigated by the cell cycle evaluation. During the test, the cells stained with propidium iodide, the fluorochrome substance which intercalates into the DNA of cells, were analyzed by use flow cytometer. This approach allows for measurement of the percentage of cells in each cell cycle phases as well as the proportion of dead cells in the studied sample (Fig. 1). On the basis of the percentage of cells in S phase, we estimated the proliferative activity of cells, also cells before mitosis in the G2/M phase. After incubation with platinum nanoparticles, the cells were detached from plates by use $0,25 \%$ TrypsinEDTA buffer (Biowest) and washed twice with PBS buffer. Next, cell pellets were re-suspended in $500 \mu$ l of cold permeabilization buffer, BD Perm/Wash Buffer (BD Biosciences), and incubated for $30 \mathrm{~min}$ at $4{ }^{\circ} \mathrm{C}$. After centrifugation at $400 \mathrm{~g}$ for $5 \mathrm{~min}$, pellets were re-suspended in $1 \mathrm{~mL}$ cold PBS containing $10 \mathrm{mg} / \mathrm{mL}$ propidium iodide (Sigma-Aldrich) and $100 \mathrm{U} / \mathrm{mL}$ RNase enzyme (Boehringer Mannheim), and incubated for $30 \mathrm{~min}$ at $4{ }^{\circ} \mathrm{C}$ protected from light. Then, the 


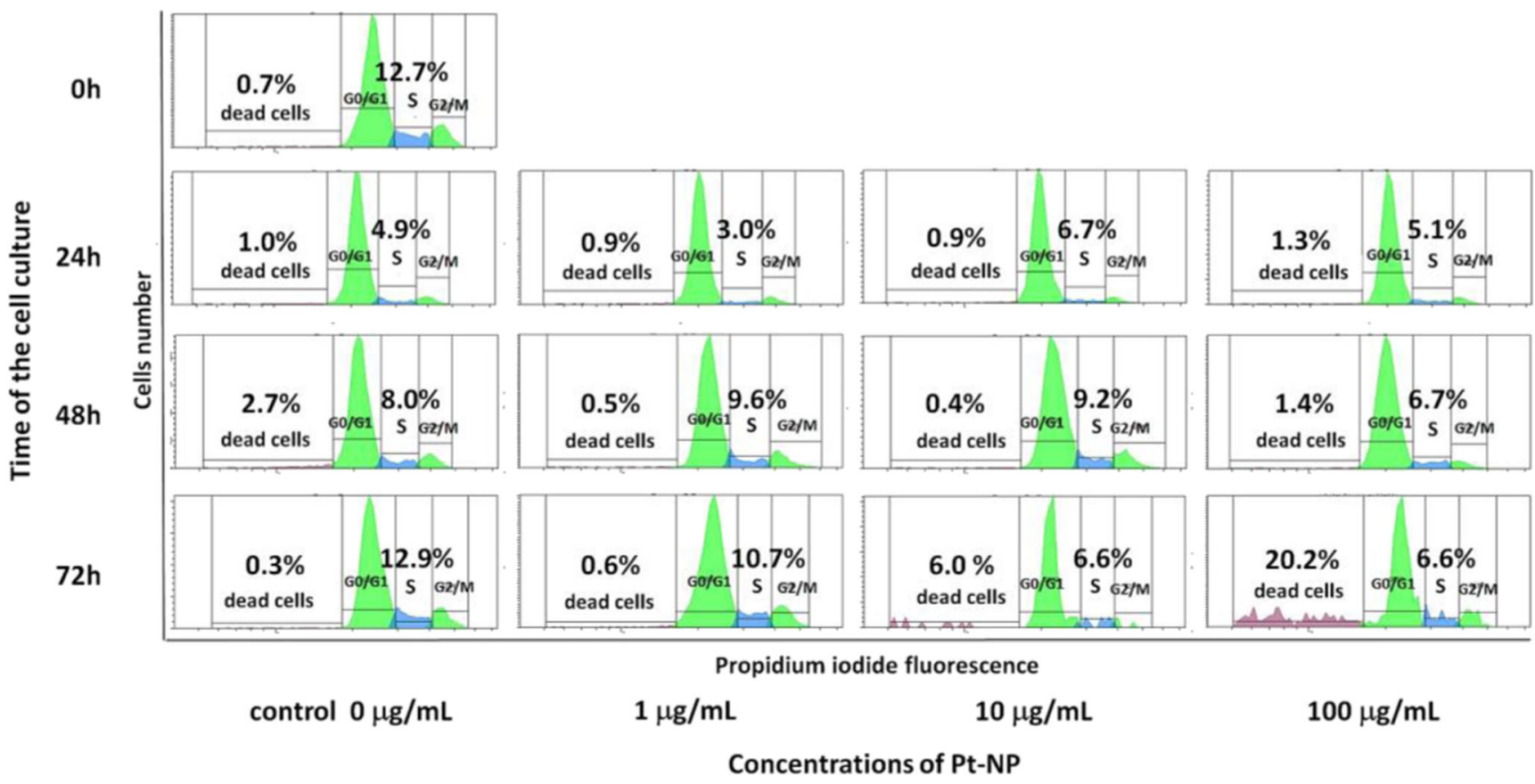

Fig. 1 Histograms presented the cell cycle analysis of the A549 cell line cultured under the influence of platinum nanoparticles in $1 \mu \mathrm{g} / \mathrm{mL}, 10 \mu \mathrm{g} / \mathrm{mL}$, and $100 \mu \mathrm{g} / \mathrm{mL}$ concentration

samples were acquired by using the flow cytometer FACS Canto (Becton Dickinson) and analyzed using FACS Diva software (Becton Dickinson). The results were tested with one-way non-parametric ANOVA (Kruskal-Wallis test).

\section{Results and discussion}

\subsection{UV VIS studies of platinum nanoparticles}

UV-vis spectroscopy is absorption spectroscopy used to confirm the synthesis of nanoparticles and nanocomposites. It was employed in this work to determine the presence of synthesized platinum nanoparticles. Figure 2 presents the UVvisible spectra of platinum nanoparticles synthesized using O.radix extract. The absorbance was measured after the solution had been stirred magnetically for $5 \mathrm{~h}$ at the temperature of $80^{\circ} \mathrm{C}$, and the absorption peak was recorded at $265 \mathrm{~nm}$. The reaction was continued for the next $5 \mathrm{~h}$. After that time, it was observed that as the incubation time increased, the intensity of the absorption peak at $265 \mathrm{~nm}$ significantly lowered. Finally, it disappeared and was replaced by a broad continuous absorption spectrum between 200 and $300 \mathrm{~nm}$, which indicated the formation of platinum nanoparticles (Leo and Oluwafemi 2017). During mixing, a change of color was observed: from yellow to yellowish brown. This indicated that platinum nanoparticles were formed due to the reduction process of $\mathrm{Pt}^{4+}$ to $\mathrm{Pt}^{0}$ nanoparticles.

\subsection{Fourier transform infrared spectroscopy (FTIR) studies of platinum nanoparticles}

Figure 3 presents the results of the FTIR analysis of platinum nanoparticles synthesized using $O$. radix extract. To find the functional groups involved in the bioreduction of platinum nanoparticles, Fourier transform infrared spectroscopy (FTIR) measurements were carried out. The strong peaks were observed at $3309 \mathrm{~cm}-1,2119 \mathrm{~cm}-1,1635 \mathrm{~cm}-1,417 \mathrm{~cm}$ -1 and $387 \mathrm{~cm}^{-}$. The strong absorption peak that appeared at $3309 \mathrm{~cm}-1$ is related to O-H stretching (intramolecular hydrogen bonded $\mathrm{OH})$. The band which appeared at $2119 \mathrm{~cm}-1$ indicates the presence of an alkyne group. The most intense band at $1635 \mathrm{~cm}-1$ represents vibrations $\mathrm{C}=\mathrm{O}$, typical of the structure of flavonoids. The most intense band at $387 \mathrm{~cm}-1$ is attributed to the deformation vibration of $\mathrm{CC}$ in polymer chains. Fourier Transform Infrared Spectroscopy (FTIR) also confirmed that O.radix contained bioactive compounds, which served as reducing and capping agents for Pt nanoparticles. The phytochemical studies on $O$. radix have determined the presence of flavonoid derivatives, sterols ( $\beta$-sitosterol, campesterol, stigmasterol, stigmastan-3,5-dien), terpenic substances, phenolic acids and essential oil (carvone, menthol, menthone, isomenthone, linalool, estragole, borneol and cisanethole (Öz et al. 2018). Another significant group of biologically active compounds found in $O$. radix are isoflavonoids. Isoflavonoids have a phenyl substituent at the 3-position of the chromane ring (3-phenylchromen-2-one-4 or 3-phenylchromen-4-one). In the studies conducted by Gampe 


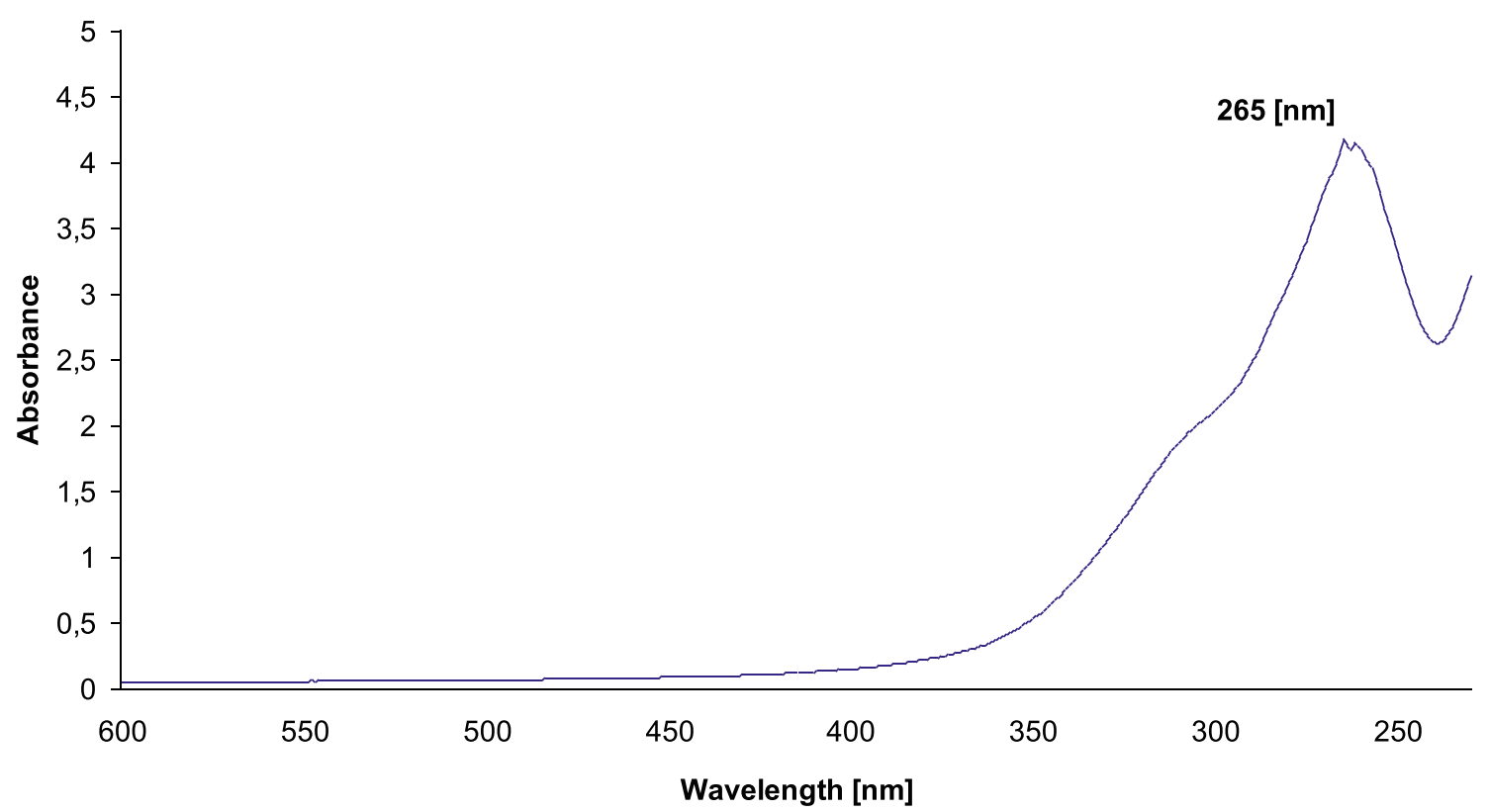

Fig. 2 UV-vis absorption spectrum of synthesized platinum nanopartilces using O.radix extract

et al. (2016), isoflavonoids (formononetin, calycosin and pseudobaptigenin), pterocarpans (medicarpin and maackiain) and dihydroisoflavonoids (onogenin and sativanone) were found in the forms of glucosides, glucoside malonates, glucoside acetates and aglycones. The studies carried out by Gampe et al. in 2018 additionally confirmed the presence of six piperidin-2-ylacetic acid (homopipecolic acid) esters of isoflavonoid glucosides. Isoflavonoids are responsible for various biological activities, such as estrogenic, antioxidant and anticancer activities (Sharma and Ramawat 2013). In the

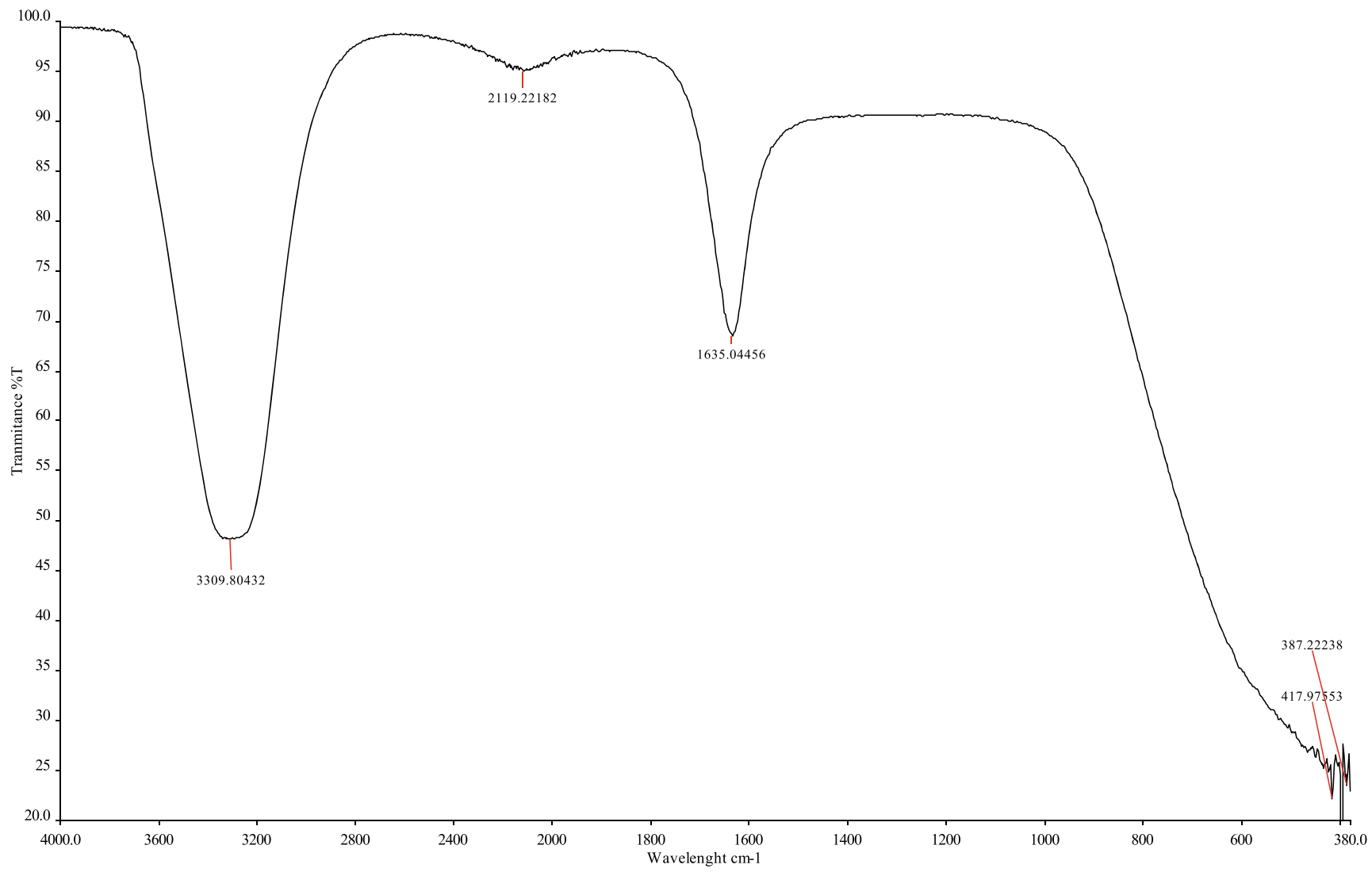

Fig. 3 FT-IR spectra of synthesized platinum nanopartilces using $O$. radix extract 
studies conducted by Wang et al. (2013) the aglycone of sativanone-7-O-glucoside was shown to possess antiinflammatory properties in vitro. Moreover, it was found that sativanone inhibited the release of TNF- $\alpha$ from polysaccharide activated macrophages. Sativanone was also found to induce expression of collagen type I and transforming growth factor-b1 in human dermal fibroblasts (Ham et al. 2015). According to the literature (Wilska-Jeszka and Podsędek 2001), the antioxidant properties of flavonoids are determined by the presence of hydroxy groups in both rings, the isomerism of their position, and the presence of a double bond and a carbonyl group in the heterocyclic ring. A stronger antioxidant potential is exhibited by flavonoids which have a greater number of hydroxy groups that are located in the para position. In addition, it was discovered that the differences in antioxidant properties also depend on the type of the saccharide residue present in the particle. $O$. radix also contains phenolic acids (p-hydroxybenzoic, vanillic acid, caffeic acid, syringic acid, p-coumaric acid, cinnamic acid, sinapin acid, salicylic acid, gentisin acid), which have antioxidant properties as well. Sinapinic acid with two methoxy groups is more active than ferulic acid, which has one methoxy group, and the latter is more active than coumaric acid (which has one hydroxy group) (Rice-Evans et al. 1996). Figure 4 presents the chemical structure of isoflavonoids: (A) formononetin, (B) calycosin, (C) pseudobaptigenin and (D) medicarpin.

\subsection{Transmission (TEM) and scanning Electron microscopy (SEM) with EDS profile of platinum nanoparticles}

Transmission Electron Microscope Analysis (TEM) and Scanning Electron Microscopy (SEM) measurements were used to determine the size, shape and morphological features of platinum nanoparticles synthesized using O.radix extract. Transmission Electron Microscopy images (Fig. 5a and b) confirmed the presence of spherical and hexagonal platinum nanoparticles. Scanning Electron Microscopy (SEM) determined the presence of platinum nanoparticles whose size was about $20 \mathrm{~nm}$ (Fig. 5c and e). Şahin et al. (2018) who synthesized platinum nanoparticles with the use of pomegranate extract, also obtained spherical shape and a similar size. Pal et al. (2014) produced spherical platinum nanoparticles by means of microwave irradiation. Spherical nanoparticles were also obtained by Syed and Ahmad (2012), who conducted the biosynthesis of platinum nanoparticles using the fungus a<smiles>COc1ccc(-c2coc3cc(O)ccc3c2=O)cc1</smiles>

b<smiles>COc1ccc(-c2coc3cc(O)ccc3c2=O)cc1O</smiles>

C

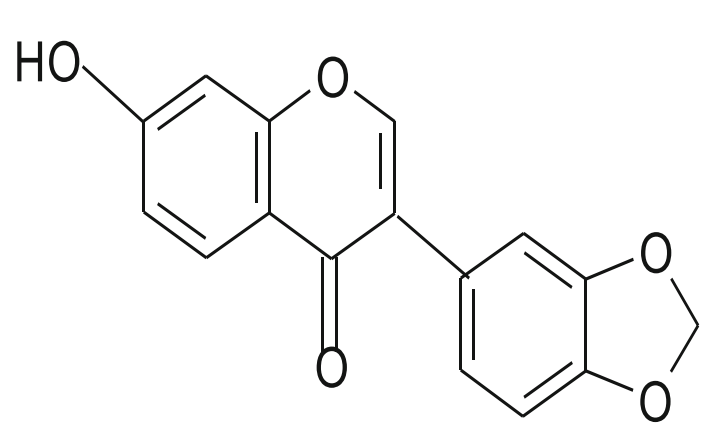

d

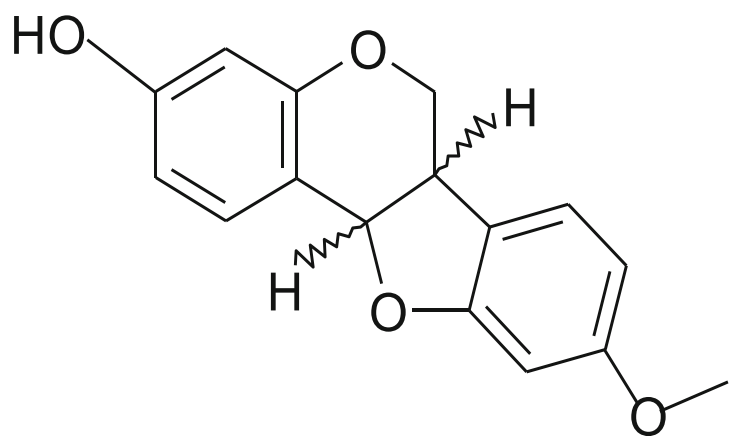

Fig. 4 The chemical structure of of isoflavonoids: a formononetin, $\mathbf{b}$ calycosin, $\mathbf{c}$ pseudobaptigenin and (d) medicarpin 
a

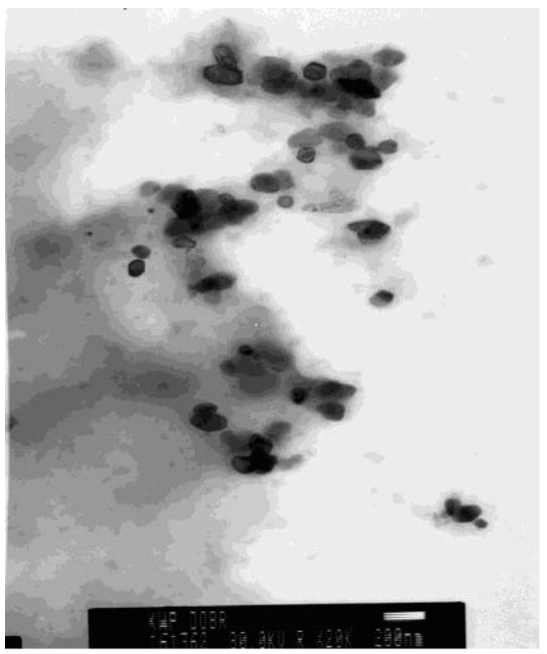

C

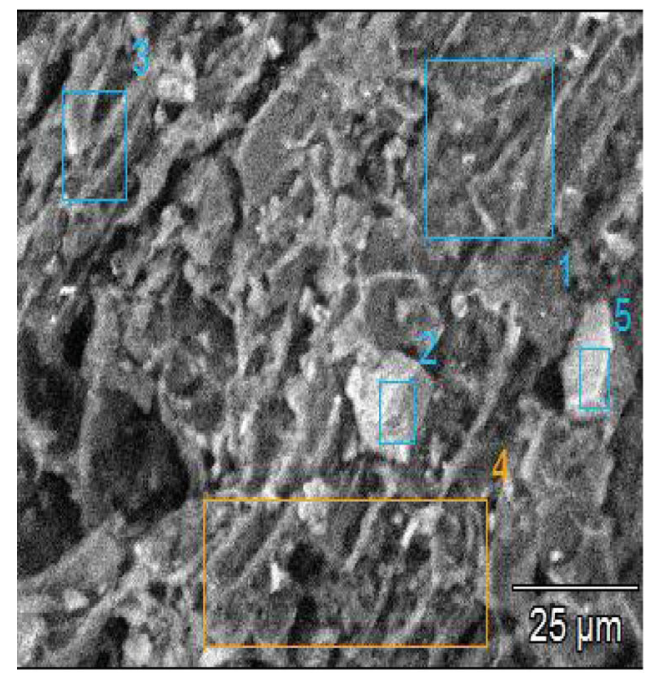

e

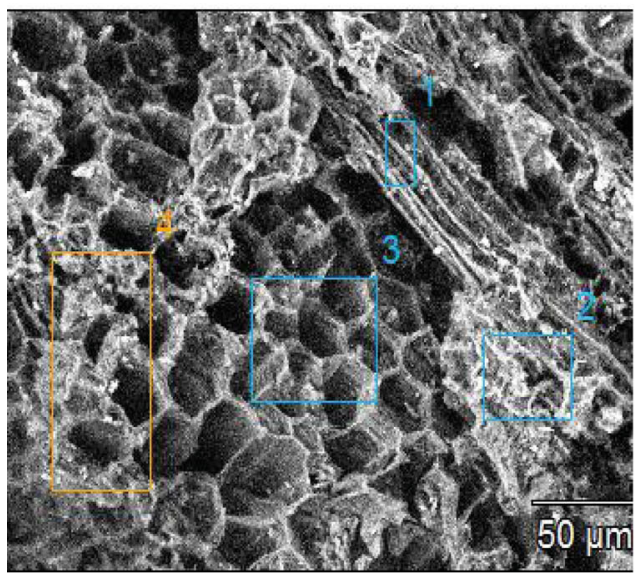

b

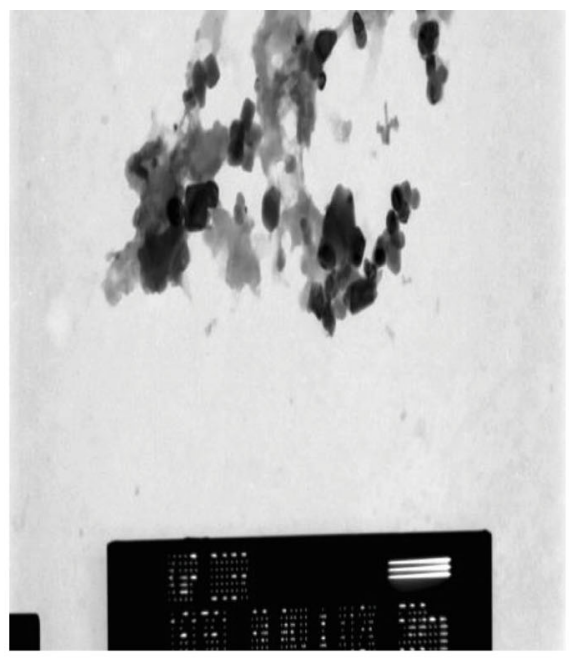

d

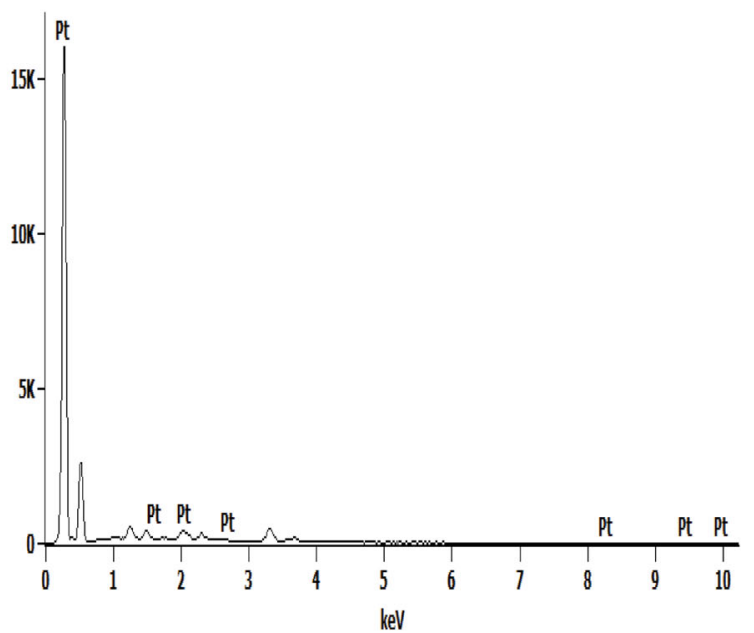

$\mathbf{f}$

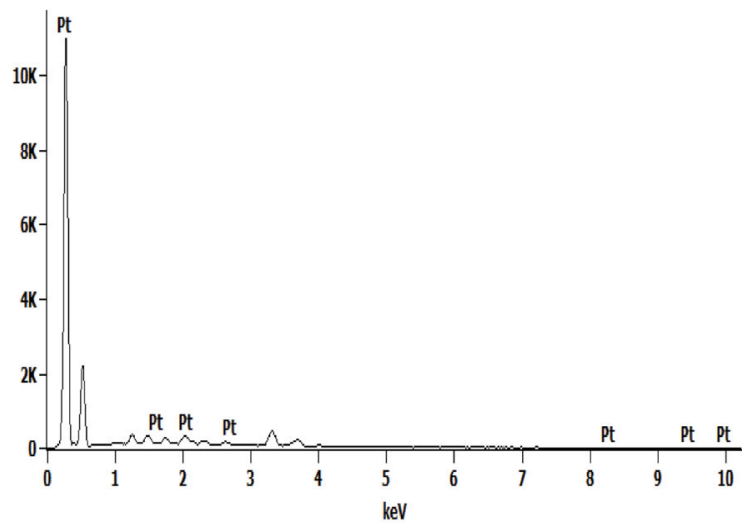

Fig. 5 TEM and SEM images of synthesized platinum nanoparticles using O.radix extract at different scale bar (a) $200 \mathrm{~nm}$ (b) $500 \mathrm{~nm}$, (c) $25 \mu \mathrm{m}$ with (d) EDS profile and (e) $50 \mu \mathrm{m}$ with (f) EDS profile 
a
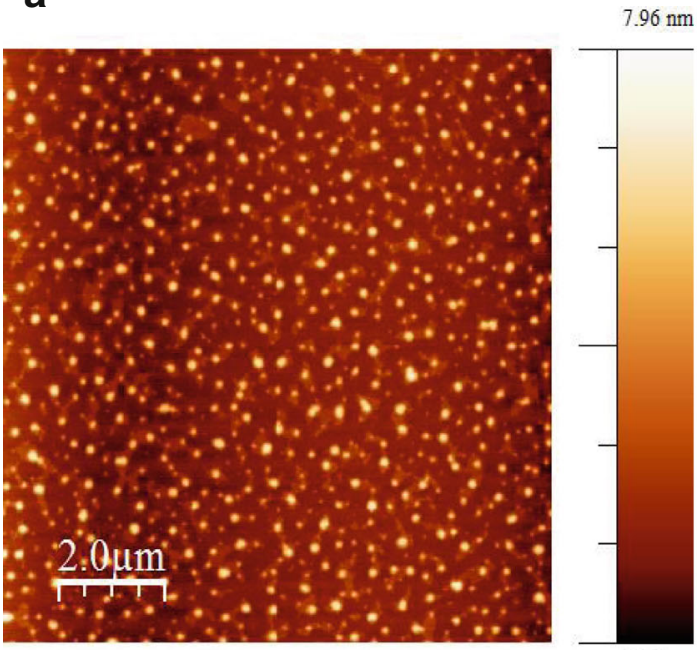

$0.00 \mathrm{~nm}$ b

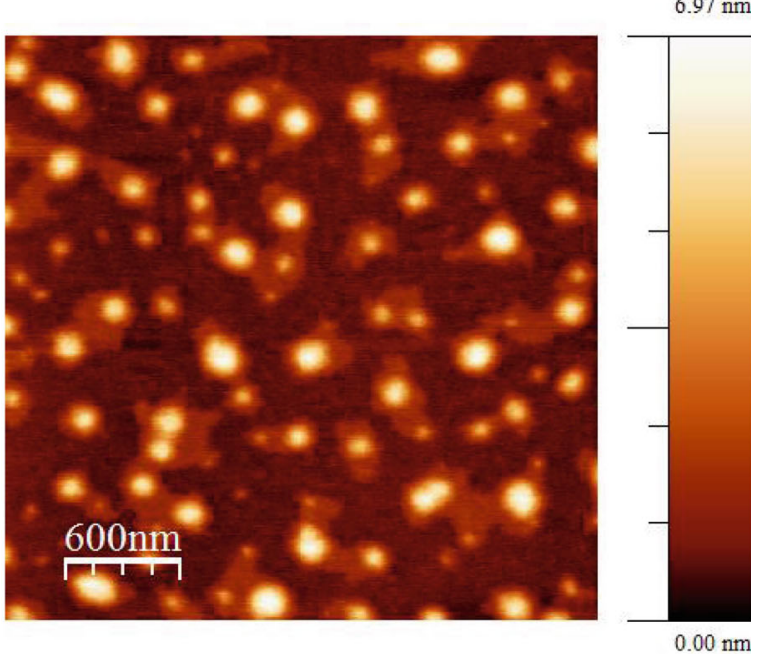

C

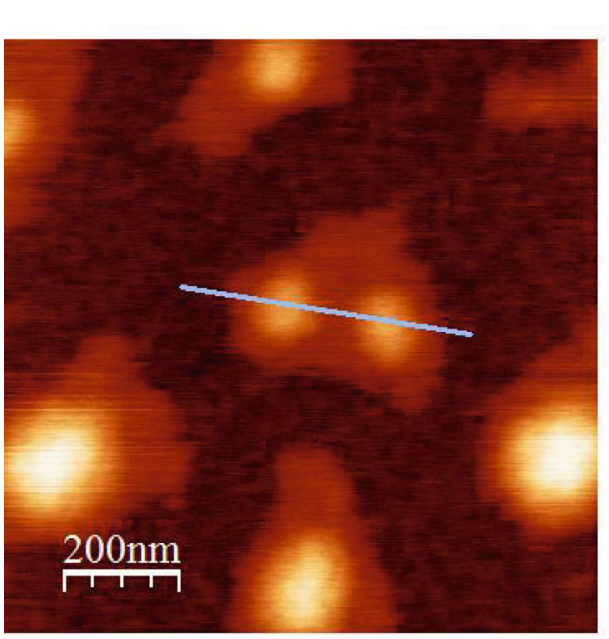

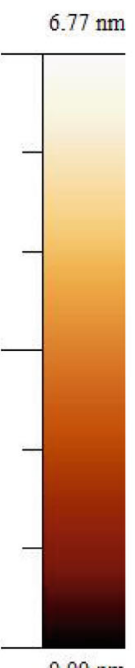

d

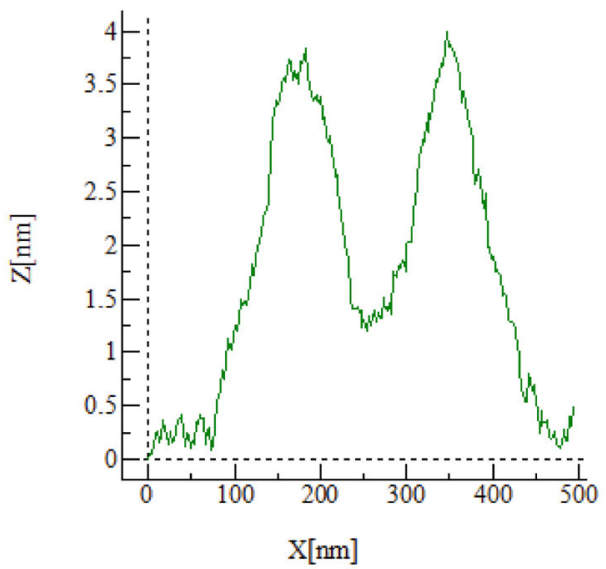

Fig. 6 AFM images of synthesized platinum nanoparticles using O.radix extract (a) the topography for AFM $10 \mu \mathrm{m} \times 10 \mu \mathrm{m}, \mathbf{b}$ the topography for AFM $3 \mu \mathrm{m} \times 3 \mu \mathrm{m}, \mathbf{c}$ the topography for AFM $1 \mu \mathrm{m} \times 1 \mu \mathrm{m}$ with the section by nanoparticles and (d) intersection for AFM $1 \mu \mathrm{m} \times 1 \mu \mathrm{m}$

Fusarium oxysporum. Quasi-spherical shape of platinum nanoparticles was obtained by Kora and Rastogi (2018), who carried out the synthesis using gum olibanum Boswellia serrata. Sheny et al. (2013), using the leaves of Anacardium occidentale, synthesized crystalline and irregular rod-shaped Pt nanoparticles. Those results prove that there is a strong correlation between the shape of nanoparticles and the biological material used, i.e. the active substances in a given plant. According to Huang et al. (2007), when a larger concentration of bio-reducing agent is used, there occurs a relatively fast nucleation process, which is followed by a slower growing stage due to stronger interactions between protective biomolecules and growth, leading to the formation of more isotropic particles.
The work also presents the EDS profile, which provides additional evidence of the reduction of platinum nanoparticles. Figure $5 \mathrm{~b}$ and d depicts seven peaks between $0 \mathrm{kV}$ and $10 \mathrm{kV}$. Those results indicated that the reaction product was composed of high purity platinum nanoparticles.

\subsection{Atomic force microscopy (AFM) studies of platinum nanoparticles}

The size and shape of the obtained platinum nanoparticles were confirmed by means of atomic force. The obtained results made it possible to determine the presence of platinum nanoparticles with the same shape as shown before by means of Transmission Electron Microscopy. However, Atomic 


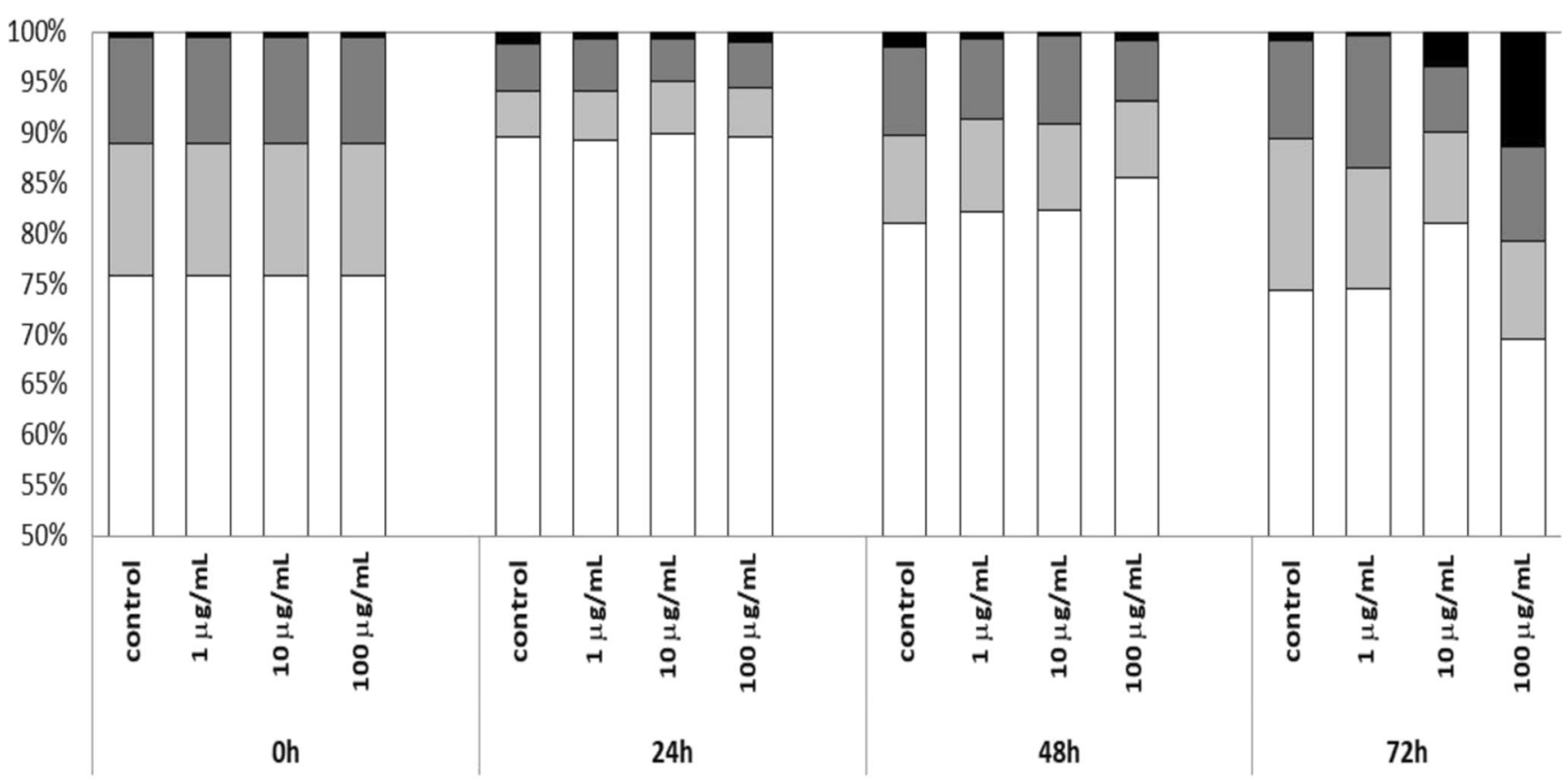

$\square$ G0/G1 phase $\quad$ QSphase $\quad$ G2/M phase $\quad$ dead cells

Fig. 7 Analysis of the cell cycle of the A549 line cultured under the influence of synthesized platinum nanoparticles in following time points of $24 \mathrm{~h}$, $48 \mathrm{~h}$, and $72 \mathrm{~h}$

Force Microscopy indicated the presence of smaller platinum nanoparticles, whose size was about $4 \mathrm{~nm}$. Higher results obtained by means of TEM and SEM measurements stem from the agglomeration of nanoparticles. As we are dealing with biological material, particles may agglomerate. Figure 6 presents AFM image of synthesized platinum nanoparticles using $O$. radix with (A) the topography of $10 \mu \mathrm{m} \times 10 \mu \mathrm{m},(\mathrm{B})$ the topography of $3 \mu \mathrm{m} \times 3 \mu \mathrm{m},(\mathrm{C})$ the topography of $1 \mu \mathrm{m} \times$

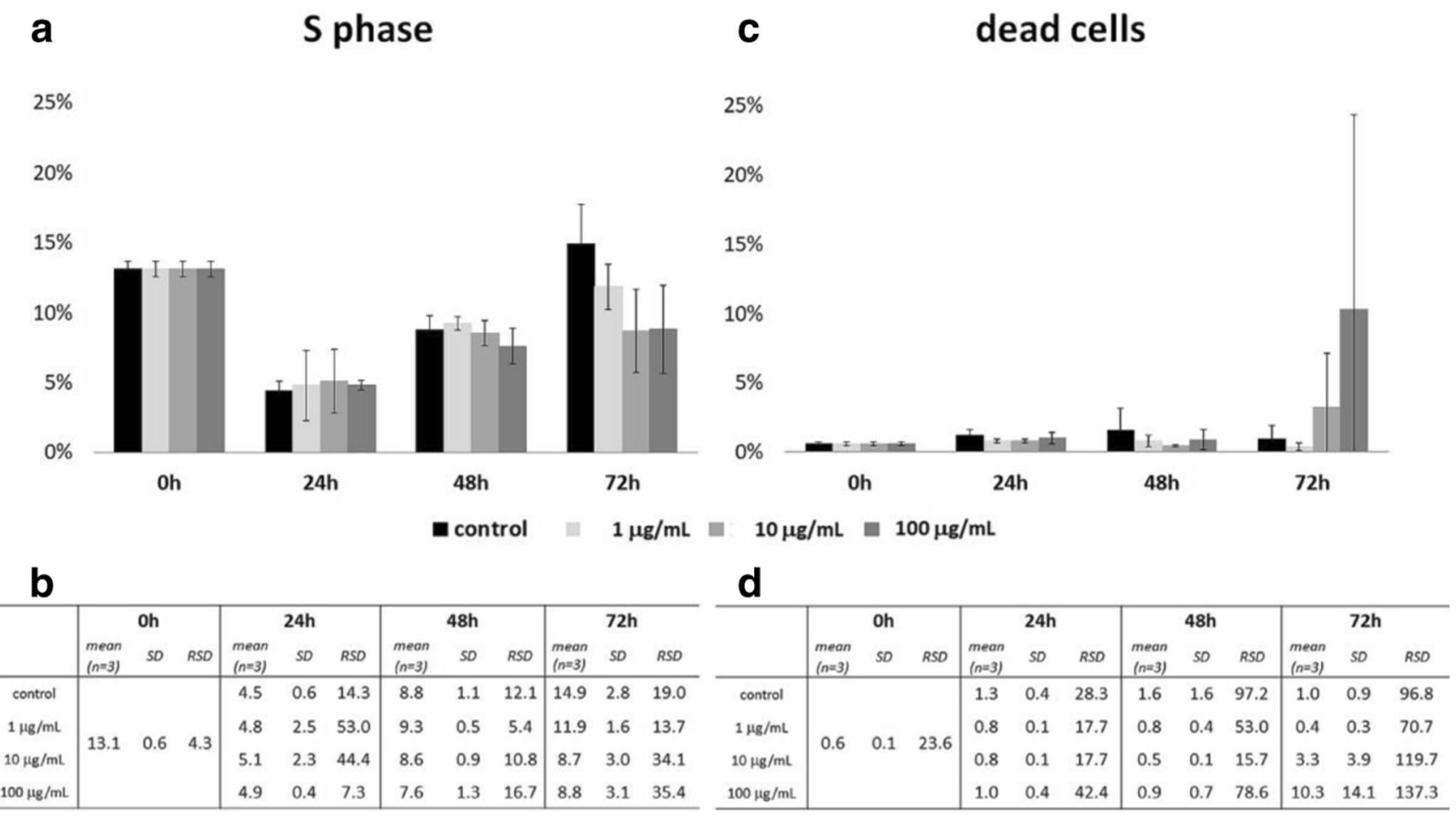

Fig. 8 Evaluation of the percentage of A549 cells cultured under the influence of synthesized platinum nanoparticles in the S phase of the cell cycle and the proportion of dead cells 
$1 \mu \mathrm{m}$ with the section by nanoparticles and (D) the profile for AFM $1 \mu \mathrm{m} \times 1 \mu \mathrm{m}$.

\subsection{Results of the cell cycle analysis}

Mohammadi et al. showed that platinum nanoparticles have anticancer properties (Mohammadi et al. 2013). They examined the cytotoxicity of platinum nanoparticles by MTT assay on MCF-7 and HepG-2 cell lines. The obtained results demonstrated concentration-dependent toxicity for the tested cells. Moreover, platinum nanoparticles exhibited potent anticancer activity against PA-1 cell line via induction of apoptosis and cell cycle arrest (Bendale et al. 2017). According to the literature, the anticancer activity of platinum nanoparticles is associated with the inhibition of DNA replication and mitosis by the addition of platinum nanoparticles to the DNA strand (Sawosz et al. 2010). Platinum nanoparticles penetrate into the nucleus and mitochondria, binding with DNA molecule and leading to cellular apoptosis (Ullah et al. 2017).

Al-Radadi and Najlaa (2019) demonstrated the anticancer activity of platinum nanoparticles against different cancer cells, including the colon carcinomab cells (HCT-116), breast cells (MCF-7), and hepatocellular carcinoma (HePG-2). In this study, the influence of platinum nanoparticles on human non-small cell lung carcinoma cells A549 was examined. Performed analysis of the cell cycle showed increasing of mortality of cells cultured together with the synthesized platinum nanoparticles. In the beginning, the proliferative activity of A549 cells under the influence of studied substance was higher as compared to the control. In the course of time of the culture, the percentage of dead cells was more significant (Fig. 7). The maximum mortality of cells was observed in the $72 \mathrm{~h}$ of the test in the sample where cells were cultured with the highest concentration of the platinum nanoparticles, $100 \mu \mathrm{g} / \mathrm{mL}$. The grown percentage of dead cells was observed already in the $72 \mathrm{~h}$ under the influence of platinum nanoparticles molecules at the concentration of $10 \mu \mathrm{g} / \mathrm{mL}$. Also in the $72 \mathrm{~h}$ of culture, the synthesized platinum nanoparticles in the concentration of $1 \mu \mathrm{g} / \mathrm{mL}$ inhibited the proliferation activity of studied cells, which observed value was lower as compared to the control cells. The proliferative activity of A549 cells decreased gradually over time in proportion to the increasing concentration of the test substance (Fig. 8). The bar graph of the percentage of cells in the S phase of the cell cycle compared to the percentage of dead cells clearly shows the relationship, where the inhibition of replication is associated with the increase the mortality increase. Observed phenomena are dependent on the time of cultivation and the concentration of the test substance. However, obtained results were not statistically important when they were tested with one-way nonparametric ANOVA (Kruskal-Wallis test).

\section{Conclusion}

The biological methods for synthesizing metal nanoparticles have attracted more interest in recent years. This stems, among others, from the fact that the use of such methods may eliminate or reduce the amount of waste generated by chemical and physical methods. A great advantage of this method is the low cost of the metal ion reduction process. For this reason, in this work, the biological synthesis of platinum nanoparticles was conducted using $O$. radix extract. The techniques for measuring platinum nanoparticles synthesized using $O$. radix extract, such as AFM, TEM and SEM with EDS analyzer, confirmed the presence of nanoparticles with the size of $4 \mathrm{~nm}$, which were locally agglomerated. The emergence of nanoscience has provided promising results in recent years by intersecting with various other branches of science and exercising impact on all forms of life. Nanosciene offers solutions to technological and environmental challenges in medicine. The conducted study showed the influence of platinum nanoparticles on human non-small cell lung carcinoma cells A549. The maximum mortality of cells was observed in the $72 \mathrm{~h}$ of the test, in the sample where cells were cultured with the highest concentration of platinum nanoparticles. Additionally, the proliferative activity of A549 cells decreased gradually over time in proportion to the increasing concentration of the platinum nanoparticles.

\section{Compliance with ethical standards}

Conflict of interest The authors declare that they have no conflict of interest.

Open Access This article is distributed under the terms of the Creative Commons Attribution 4.0 International License (http:// creativecommons.org/licenses/by/4.0/), which permits unrestricted use, distribution, and reproduction in any medium, provided you give appropriate credit to the original author(s) and the source, provide a link to the Creative Commons license, and indicate if changes were made.

\section{References}

B. Ajitha, Y.A.K. Reddy, P.S. Reddy, Biosynthesis of silver nanoparticles using Momordica charantia leaf broth: Evaluation of their innate antimicrobial and catalytic activities. J. Photochem. Photobiol. B Biol. 146, 1-9 (2015)

S. Al-Radadi, Najlaa, Green synthesis of platinum nanoparticles using Saudi's Dates extract and their usage on the cancer cell treatment. Arab. J. Chem. 12, 330-349 (2019)

A. Baranwal, K. Mahato, A. Srivastava, P.K. Maurya, P. Chandra, Phytofabricated metallic nanoparticles and their clinical applications. RSC Adv. 6, 105996-106010 (2016)

A. Baranwal, A.K. Chiranjivi, A. Kumar, V.K. Dubey, P. Chandra, Design of commercially comparable nanotherapeutic agent against 
human disease-causing parasite, Leishmania. Sci. Rep. 8, 8814 (2018a)

A. Baranwal, A. Srivastava, P. Kumar, V.K. Bajpai, P.K. Maurya, P. Chandra, Prospects of nanostructure materials and their composites as antimicrobial agents. Front. Microbiol. 9, 422 (2018b)

Y. Bendale, V. Bendale, S. Paul, Evaluation of cytotoxic activity of platinum nanoparticles against normal and cancer cells and its anticancer potential through induction of apoptosis. Int. Med. Res. 6, 141148 (2017)

I. Bhatnagar, K. Mahato, K.K.R. Ealla, A. Asthana, P. Chandra, Chitosan stabilized gold nanoparticle mediated self-assembled glip nanobiosensor for diagnosis of invasive aspergillosis. Int. J. Biol. Macromol. 110, 449-456 (2018)

P. Dauthal, M. Mukhopadhyay, Noble metal nanoparticles: Plantmediated synthesis, mechanistic aspects of synthesis, and applications. Ind. Eng. Chem. Res. 55, 9557-9577 (2016)

R. Dobrucka, Biofabrication of platinum nanoparticles using Fumariae herba extract and their catalytic properties. Saudi J. Biol. Sci. 26, 31-37 (2016)

N. Gampe, A. Darcsi, S. Lohner, S. Béni, L. Kursinszki, Characterization and identification of isoflavonoid glycosides in the root of spiny restharrow (Ononis spinosa L.) by HPLC-QTOF-MS, HPLC-MS/ MS and NMR. J. Pharm. Biomed. Anal. 123, 74-81 (2016)

N. Gampe, A. Darcsi, L. Kursinszki, S. Béni, Separation and characterization of homopipecolic acid isoflavonoid ester derivatives isolated from Ononis spinosa L. root. J. Chromatogr. B 1091, 21-28 (2018)

C.D. Ham, M.R. Nelson, S. Das, How to measure persuasion knowledge. Int. J. Advert. 34, 17-53 (2015)

J. Huang, Q. Li, D. Sun, Y. Lu, Y. Su, X. Yang, J. Hong, Biosynthesis of silver and gold nanoparticles by novel sundried Cinnamomum camphora leaf. Nanotechnology 18, 105-104 (2007)

Z.U.H. Khan, A. Khan, Y. Chen, N.S. Shah, N. Muhammad, A.U. Khan, S.A. Qaisrani, Biomedical applications of green synthesized Nobel metal nanoparticles. J. Photochem. Photobiol. B Biol. 173, 150-164 (2017)

A.J. Kora, L. Rastogi, Peroxidase activity of biogenic platinum nanoparticles: A colorimetric probe towards selective detection of mercuric ions in water samples. Sensors Actuators B Chem. 254, 690-700 (2018)

A.J. Leo, O.S. Oluwafemi, Plant-mediated synthesis of platinum nanoparticles using water hyacinth as an efficient biomatrix source-An eco-friendly development. Mater. Lett. 196, 141-144 (2017)

H. Mohammadi, A. Abedi, A. Akbarzadeh, M.J. Mokhtari, H.E. Shahmabadi, M.R. Mehrabi, M. Chiani, Evaluation of synthesized platinum nanoparticles on the MCF-7 and HepG-2 cancer cell lines. Int. Nano Lett. 3(28) (2013)

H. Nadaroglu, A.A. Gungor, S. Ince, A. Babagil, Green synthesis and characterisation of platinum nanoparticles using quail egg yolk. Spectrochim. Acta A Mol. Biomol. Spectrosc. 172, 43-47 (2017)

K.B. Narayanan, N. Sakthivel, Biological synthesis of metal nanoparticles by microbes. Adv. Colloid Interf. Sci. 156, 1-13 (2010)

M. Nasrollahzadeh, S.M. Sajadi, A. Hatamifard, Waste chicken eggshell as a natural valuable resource and environmentally benign support for biosynthesis of catalytically active $\mathrm{Cu} /$ eggshell, $\mathrm{Fe}_{3} \mathrm{O}_{4}$ /eggshell and $\mathrm{Cu} / \mathrm{Fe}_{3} \mathrm{O}_{4} /$ eggshell nanocomposites. Appl. Catal. B Environ. 191, 209-227 (2016)

B.E. Öz, G.S. İşcan, E.K. Akkol, İ. Süntar, Ö.B. Acıkara, Isoflavonoids as wound healing agents from Ononidis Radix. J. Ethnopharmacol. 211, 384-393 (2018)

J. Pal, M.K. Deb, D.K. Deshmukh, B.K. Sen, Microwave-assisted synthesis of platinum nanoparticles and their catalytic degradation of methyl violet in aqueous solution. Appl. Nanosci. 4, 61-65 (2014)

F.A.A. Rajathi, V.R.M.S. Nambaru, Phytofabrication of nano-crystalline platinum particles by leaves of Cerbera manghas and its antibacterial efficacy. Int J Pharm. Bio. Sci 5, 619-628 (2014)

C.A. Rice-Evans, N.J. Miller, G. Paganga, Structure-antioxidant activity relationships of flavonoids and phenolic acids. Free Radic. Biol. Med. 20, 933-956 (1996)

B. Șahin, A. Aygün, H. Gündüz, K. Șahin, E. Demir, S. Akocak, F. Șen, Cytotoxic effects of platinum nanoparticles obtained from pomegranate extract by the green synthesis method on the MCF-7 cell line. Colloids Surf. B: Biointerfaces 163, 119-124 (2018)

E. Sawosz, A. Chwalibog, J. Szeliga, F. Sawosz, M. Grodzik, M. Rupiewicz, K. Kacprzyk, Visualization of gold and platinum nanoparticles interacting with Salmonella enteritidis and listeria monocytogenes. Int. J. Nanomedicine 5, 631 (2010)

V. Sharma, K.G. Ramawat, Salinity-induced modulation of growth and antioxidant activity in the callus cultures of miswak (Salvadora persica). 3 Biotech 3, 11-17 (2013)

D.S. Sheny, D. Philip, J. Mathew, Synthesis of platinum nanoparticles using dried Anacardium occidentale leaf and its catalytic and thermal applications. Spectrochim. Acta A Mol. Biomol. Spectrosc. 114, 267-271 (2013)

A. Syed, A. Ahmad, Extracellular biosynthesis of platinum nanoparticles using the fungus Fusarium oxysporum. Colloids Surf. B: Biointerfaces 97, 27-31 (2012)

K.N. Thakkar, S.S. Mhatre, R.Y. Parikh, Biological synthesis of metallic nanoparticles. Nanomedicine 6, 257-262 (2010)

A. Thirumurugan, P. Aswitha, C. Kiruthika, S. Nagarajan, A.N. Christy, Green synthesis of platinum nanoparticles using Azadirachta indica-An eco-friendly approach. Mater. Lett. 170, 175-178 (2016)

S. Ullah, A. Ahmad, A. Wang, M. Raza, A.U. Jan, K. Tahir, Y. Qipeng, Bio-fabrication of catalytic platinum nanoparticles and their in vitro efficacy against lungs cancer cells line (A549). J. Photochem. Photobiol. B Biol. 173, 368-375 (2017)

K. Vijayaraghavan, T. Ashokkumar, J. Environ. Chem. Eng. 5, 48664883 (2017)

J. Wang, W. Jiang, Y. Wang, Anti-inflammation of flavonoid compounds from Dalbergia odorifera T. Chen in lipopolysaccharide stimulated RAW264.7 macrophages. Chinese. J. Cell. Mol. Immunol. 29, 681684 (2013)

J. Wilska-Jeszka, A. Podsędek, Bioflavonoids as natural antioxidants. Wiad. Chem. 55, 987-1003 (2001)

Publisher's note Springer Nature remains neutral with regard to jurisdictional claims in published maps and institutional affiliations. 